\title{
Neutral effect of an invasive plant species with specialized flower structure on native pollinator communities
}

\author{
Viktor Szigeti 1 • Annamária Fenesi · Zoltán Soltész • Boglárka Berki • \\ Anikó Kovács-Hostyánszki
}

Received: 4 December 2019/Accepted: 20 June 2020/Published online: 2 July 2020

(C) The Author(s) 2020

\begin{abstract}
Invasive plants modify native plant communities with serious consequences on plant-pollinator interactions. Invasion by common milkweed (Asclepias syriaca L.) threatens natural and agricultural habitats in Europe, with unknown effects on pollinators. Its special flower structure, habitat requirements and phenology offer novel insights into pollination ecology aspects of plant invasion. We compared flowering plant and pollinator communities between invaded and control sites, and the flower visitors between native plants and common milkweed.
\end{abstract}

Electronic supplementary material The online version of this article (https://doi.org/10.1007/s10530-020-02305-6) contains supplementary material, which is available to authorized users.

\section{Szigeti $(\bowtie) \cdot$ Z. Soltész · B. Berki ·}

A. Kovács-Hostyánszki

Lendület Ecosystem Services Research Group, Institute of

Ecology and Botany, Centre for Ecological Research,

Vácrátót, Hungary

e-mail: szigeti.viktor@gmail.com

\section{A. Fenesi}

Hungarian Department of Biology and Ecology, Babeş-

Bolyai University, Cluj-Napoca, Romania

\section{Z. Soltész}

Hungarian Natural History Museum, Budapest, Hungary

\section{B. Berki}

Large-Scale Vegetation Ecology Research Group, Institute of Ecology and Botany, Centre for Ecological

Research, Vácrátót, Hungary
Wild bees and hoverflies did not differ in abundance, diversity and community composition between the invaded and control sites. However, honey bees and bumble bees preferred milkweed above native plants during milkweed flowering. In contrast to many studies, our results suggest neutral effect of plant invasion on the sampled aspects of diurnal wild pollinator community, while providing resources for a few pollinator taxa. This neutral effect might be explained by the long-term, wide scale distribution of milkweed and/or its typically relatively low coverage compared to many other invasive plants, enabling the persistence of some native flowering species. However, its special flower structure offers nectar only for a few common pollinators, including honey bee, and it decreases abundance of native flowers in spring with unknown consequences on wild bees' reproduction success. Despite the lack of direct negative effects on wild pollinators, restoration of invaded habitats to promote native floral communities is suggested to enable diverse, longer lasting foraging resources for wild pollinators and honey bees. Promoting actively wildflower habitats might be vital for beekeepers in the case of milkweed eradication.

Keywords Alien species - Asclepias syriaca . Hoverfly $\cdot$ Milkweed · Plant-pollinator interaction . Wild bee 


\section{Introduction}

Invasive plant species often profoundly modify the abundance and the diversity of native plant species, and sustain an alternative vegetation state by halting the trajectory of succession (Meiners et al. 2002; Cramer et al. 2008; Fenesi et al. 2015). Such changes on plant communities can have an impact on the related animal communities, such as pollinator insects and their pollination service (Bezemer et al. 2014; Traveset and Richardson 2014; van Hengstum et al. 2014). Invasive plant species can exert influence on native pollinator communities by outcompeting native plant species with insect-pollinated flowers, through their attractive and/or abundant flowers in the "floral market" (Chittka and Schürkens 2001; Larson et al. 2006; Goodell and Parker 2017). Both aspects change remarkably the resource availability and diversity for pollinators (Chittka and Schürkens 2001; Larson et al. 2006; Nielsen et al. 2008), resulting in significant impact on population of pollinator insects and their pollination service as well (Bezemer et al. 2014; Traveset and Richardson 2014; van Hengstum et al. 2014).

Although insect pollination is crucial in the functioning of almost all terrestrial ecosystems due to plant reproduction (Potts et al. 2016; Ollerton 2017), including the majority of cultivated crops (Klein et al. 2007), understanding how resilient pollinator communities are to plant invasion is still not sufficiently understood (Dicks et al. 2013; Stout and Tiedeken 2017; Knight et al. 2018). Sometimes invasive plants could have a neutral effect (Ghazoul 2004; Nielsen et al. 2008; Nienhuis et al. 2009), but in most cases, they have direct or indirect, positive or negative impacts on the pollinators (Groot et al. 2007; Bartomeus et al. 2008; Moroń et al. 2009; Bezemer et al. 2014; Russo et al. 2016; Vanbergen et al. 2018). The plant invasion effect on pollinators can apply partly through the foraging resources, as on the one hand, flowering invasive plant species can provide additional food resources for pollinators (LopezaraizaMikel et al. 2007; Bartomeus et al. 2008; Russo et al. 2016). On the other hand, they often decrease availability and/or diversity of pollen and nectar resources in the impoverished native vegetation (Groot et al. 2007; Moroń et al. 2009; Hanula and Horn 2011; Fenesi et al. 2015). The altered pollinator community can further boost the plant invasion: the reduced pollinator visits and/or pervasive inter-specific pollen transfer decrease reproduction success and diversity of the native flora (Chittka and Schürkens 2001; Carvalheiro et al. 2014; but see Charlebois and Sargent 2017), and increase the reproduction success on the highly visited invasive plant species (Stout and Tiedeken 2017).

Invasive plant species have very diverse morphological and phenological traits, therefore they can have various effects on different pollinators (Morales and Traveset 2009; Stout and Tiedeken 2017; Davis et al. 2018). Hence, understanding how resilient pollinator communities are to plant invasion cannot be sufficient without species specific studies (Dicks et al. 2013; Stout and Tiedeken 2017; Knight et al. 2018; Vanbergen et al. 2018). Insect pollinated invasive plant species are mostly generalist (i.e their flowers are attractive and their rewards are abundant and accessible for a wide group of pollinators), which is usually a requisite of their successful establishment (Richardson et al. 2000; Lopezaraiza-Mikel et al. 2007; Albrecht et al. 2014). However, there are some successful invasive plant species that are specialist regarding their favorable flower-visitors, generating still unknown, but possibly different effects on pollinator communities compared to the generalist invaders. Moreover, the effect of invasive plants on plantpollinator communities can vary across spatio-temporal scales based on e.g. the timing of flowering, spatial flower aggregations, population dynamics and home ranges of pollinators, as well as landscape heterogeneity (Larson et al. 2006; Bartomeus et al. 2010; Hulme et al. 2013; Albrecht et al. 2016). Therefore studying the invaded ecosystems during the whole season and at different organization levels is worth to reveal the complexity of plant invasion effects (Stout and Tiedeken 2017; Vanbergen et al. 2018).

The invasion of insect-pollinated plants can have socio-economic implications as well, as some invasive plant species are preferred by honey bees and thus are favored by beekeepers in honey production, playing an important economic role in East-Europe (Farkas and Zajácz 2007; Vítková et al. 2017). The conservation effort to eliminate these species often raise conflicts between conservationists and beekeepers (Fehér 2004; Szalóky 2004; Botta-Dukát and Balogh 2008; Vítková et al. 2017). Therefore understanding the role of nonnative plant species in the diet of honey bees, and the potential effect on wild pollinators has a special 
ecological and economic importance (Albrecht et al. 2016; Stout and Tiedeken 2017; Vítková et al. 2017; Knight et al. 2018).

In our study, we focus on one of the most increasingly dominant, hazardous invasive weed species in Central-Eastern Europe, the common milkweed (Asclepias syriaca L.). On the one hand this species is a serious threat for nature conservation (Botta-Dukát and Balogh 2008; Novák et al. 2011; Lapin 2017), appeared on the narrow list of invasive species in the European Union since 2017 (EU list 2017). On the other hand it is a highly favored plant in honey production by beekeepers (Farkas and Zajácz 2007; Botta-Dukát and Balogh 2008).

The effects of common milkweed on the native plant-pollinator communities has not been studied so far, however it is a unique invasive plant species regarding plant-pollinator interactions due to some traits: (1) compared to several generalist invasive plant species it has ball-shaped large inflorescences of a rather specific structure (Liede and Weberling 1995), which provides vast amount of nectar hidden in the hood-like saccules of the corolla (Willson and Bertin 1979; Farkas and Zajácz 2007) primarily for mediumlong tongued bees, butterflies and moths (Willson and Bertin 1979; Morse and Fritz 1983; Fenster et al. 2004). The pollen is located in small packets called pollinia that can be carried only by large insects. Pollinators can become trapped in flowers, lose a leg or even die as a result of the floral morphology (Morse 1981). (2) Milkweed mostly invades sandy, degraded habitats that are poor in plant species (Botta-Dukát and Balogh 2008; Szitár et al. 2018), hence the effect of invasion can be investigated in a relatively simple system (Olesen et al. 2002; Nielsen et al. 2008). (3) Milkweed covers invaded sites to a maximum of $50 \%$ (absolute coverage) (Kelemen et al. 2016) (in contrast to some other invasive plant species, which reach even 80-100\%, see e.g. Fenesi et al. 2015; Davis et al. 2018), leaving probably more space for some elements of the native vegetation (Szitár et al. 2018). These aspects offer a special opportunity to study the effects of an invasive plant species on pollinator communities that might have a rather different mechanism compared to other, formerly studied systems (Morales and Traveset 2009; Hulme et al. 2013; Stout and Tiedeken 2017; Davis et al. 2018). (For further information on common milkweed see SM. Detailed information on the studied invasive plant species).
We aimed to study effects of invasion by common milkweed on bees and hoverflies as well as their floral resources. We used an observational approach in paired invaded and non-invaded sites. Samples were taken before, during and two times after the flowering of common milkweed to reveal the temporal differences during the season. First, we were interested in the differences between the invaded and control sites in the abundance, species richness and diversity of three pollinator groups, namely honey bees, wild bees and hoverflies. Second, we studied the effects of the floral resources and the cover of the invasive species on the three different pollinator groups. Third, we analyzed the community composition of pollinators of both invaded and control sites. Fourth, we studied whether there is any competition between milkweed and native plants for pollination, namely whether milkweed was visited by different wild bee species or is it likely to attract more bumble bees and honey bees (the main known visitors of milkweed) than native flowers. This latter perspective, especially in the case of a specialist invasive species, has rarely been investigated so far. Furthermore, we compared flower abundances, species richness, diversity and the communities of the flowering plant species between the control and invaded sites.

\section{Methods}

Study sites

We carried out field work in ten pairs of study sites in the middle (the most infected) region of Hungary (for coordinates see SM. Table 1). One of each site pairs was highly invaded by the common milkweed ("invaded sites", $>25 \%$ common milkweed (absolute) coverage), while the other one was uninvaded ("control sites", $<3 \%$ milkweed coverage; SM. Table 1), but with similar conditions (slope, exposure, succession status), vegetation type, site history and native plant species pool. In the studied open sandy vegetation (the total cover of vegetation was $81 \%$ in median, min-max 40-94\%), the relative cover of milkweed in the invaded sites was relatively low ( $46 \%$ in median, min-max 32-61\%), typical for the studied invasive species (Kelemen et al. 2016; Szitár et al. 2018). All sites were assigned in former arable lands (old fields) with different degree of recovery after the 
abandonment of the agricultural management: degraded, uncharacteristic dry or semi-dry grassland or open sand steppe (SM. Table 1). The distance between the center of paired fields was at least $327 \mathrm{~m}$ (median: $494 \mathrm{~m}$; max.: $1028 \mathrm{~m}$ ), and there was min. $5.4 \mathrm{~km}$ (median: $15.5 \mathrm{~km}$; max.: $37.5 \mathrm{~km}$ ) between the nearest site pairs. Some study sites were mowed or grazed during the season (see SM. Table 1). The landscape composition did not differ between the invaded and control sites (see SM. Analyses of landscape composition), hence it was not applied in our further analyses.

\section{Sampling}

We sampled bees (Hymenoptera: Apoidea: Apiformes) and hoverflies (Diptera: Syrphidae) along two $2 \mathrm{~m}$ wide, $100 \mathrm{~m}$ long parallel transects $30 \mathrm{~m}$ apart per study site, at four dates: before the flowering of common milkweed (in May), during the peak flowering of milkweed (June) and two times after its flowering (July and September) in 2018. We conducted field work in sunny hours when the temperature was between 20 and $30^{\circ} \mathrm{C}$, there was no rain, and wind speed was below $15 \mathrm{~km} / \mathrm{h}$ (verified by an Extech 45158 mini thermo-anemometer).

The observer walked along each transects in net $20 \mathrm{~min}$, counted and tried to catch all bees and hoverflies with an insect net that were visiting flowers, flying or perching on the vegetation. We stored the captured individuals from the native flowers, from milkweed and captured on the wing or during basking separately. All specimens were killed by ethyl-acetate, stored in $70 \%$ ethanol and identified to species level in the laboratory.

We recorded flower abundance at species level along each pollinator survey transect. We counted flowers or inflorescences in ten $1 \mathrm{~m} \times 1 \mathrm{~m}$ quadrates per transect $10 \mathrm{~m}$ apart. In the case of inflorescences, flowers within 5 individuals were counted, and then the number of inflorescences was multiplied with the mean flower number per inflorescence (except in the case of Asteraceae, where the number of flower heads (i.e. the inflorescences) were counted and analyzed). Furthermore, we estimated the total live cover and the absolute cover of the common milkweed in three randomly placed $3 \mathrm{~m} \times 3 \mathrm{~m}$ quadrats in all sites in June.
Statistical analyses

We pooled the data of the two transects per site. We calculated the total abundance of flowers, wild bees (bee species except honey bees), honey bees and hoverflies, based on the field observation data. We calculated the number of species, Shannon diversity and community composition of floral species, wild bees and hoverflies based on the captured and identified specimens. To analyze the species composition of flower-visitors of common milkweed or native plants, we used data of the captured and separately stored flower visitor specimens only. For analyses of floral resources see SM. Floral resources section.

\section{Differences between the invaded and control sites in abundance, species richness and diversity}

We analyzed the differences in abundance, species richness and Shannon diversity of wild bees, honey bees (only abundance) and hoverflies between the invaded and control sites at the four observation dates separately. We used $p$ value adjusted paired nonparametric Brunner-Munzel tests (Munzel and Brunner 2002; Konietschke et al. 2015), due to the non-normal distribution of data, the relative small sample size and the paired design. We adjusted the $p$ values using the method of Benjamini and Hochberg (1995) for observation dates; here, we handled the investigated groups and measured values separately (e.g. we adjusted $p$ values separately for hoverfly abundances, hoverfly species richness, etc.).

\section{Effects of the floral resources and the cover of the invasive species}

As the composition of flowering native species and the abundance of both native and invasive species highly influence the abundance, species richness and diversity of pollinators (same response variable as above), we used mixed effect models with the following explanatory variables: invasion effect of common milkweed (invaded vs. control), the absolute coverage of the invasive plant, the flower abundance, the number of flowering species and the Shannon diversity of flowering species. The paired sampling structure and the seasonal effect were treated by nested random factors: site/observation date in our models. We 
applied p-value based model selection to find the best model, separately for all response variables. We applied different kinds of models according to the distribution of the response variables: zero-inflated Gaussian generalized linear mixed models (GLMM), Poisson GLMM (if we detected overdispersion, we corrected the standard errors using quasi-GLM models), or zero-inflated Poisson GLMMs (Venables and Ripley 2002; Zuur et al. 2009).

\section{Differences between the invaded and control sites in community composition of pollinators}

We analyzed the community composition of wild bees and hoverflies across the sites and observation dates. We used zero-adjusted Bray-Curtis dissimilarities (i.e. a dummy species with abundance $=1$ was added to all sites in all observations) (Clarke et al. 2006; Borcard et al. 2018), because we did not record any bees and hoverflies in some observation dates and/or in some sites. We applied Permutational Multivariate Analysis of Variance (PERMANOVA) (Borcard et al. 2018) to analyze the effect of different explanatory variables on the community composition separately for wild bees and hoverflies. The explanatory variables were the invasion effect of common milkweed (invaded vs. control), coverage of the invasive plant, observation date, the flower abundance, the number of flowering plant species and Shannon diversity of flowering plant species. We applied $p$ value based selection in the analyses.

We visualized the species composition along the strongly affecting explanatory variables (PERMANOVA: $\mathrm{R}^{2}>0.1$ ). We used the first two dimensions of non-metric multidimensional scaling (NMDS; Borcard et al. 2018).

\section{The effects of plant invasion on flower visitation}

To study whether milkweed was visited by different wild bee species than native flowers and to indicate any competition between milkweed and the native plants for flower visitors (as indication of potential pollination), we performed two analyses. First, we compared flower-visitor wild bee community composition on milkweed and on any native plant species in the invaded sites during the second observation date (blooming period of the common milkweed). Second, we compared flower-visitor wild bee communities from native flowers between the invaded and the control sites during the second observation date. We applied PERMANOVA in all analyses and NMDS for visualization; we used zero-adjusted Bray-Curtis dissimilarities (Clarke et al. 2006; Borcard et al. 2018). Similar analyses could not be performed on hoverflies because of their scarce flower visits on common milkweed.

Furthermore, as the specialized flowers of milkweed are favored mostly by bumble bees and honey bees, we performed two more analyses to study whether the invasive species is likely to attract more of these pollinators compared to native species. Hence, third, the abundance of flower visiting bumble bees (separated from wild bees) and honey bees on the native plants were compared between the invaded and control sites during the whole season. Fourth, we compared the abundance of flower visiting bumble bees and honey bees between the native plant species and common milkweed within the invaded sites and between the invaded and control sites during the second observation date. We used $p$ value adjusted paired Brunner-Munzel tests (Munzel and Brunner 2002; we adjusted the $p$ values using method of Benjamini and Hochberg (1995) for observation date).

The statistical analyses were carried out using $\mathrm{R}$ 3.4.4 statistical environment ( $\mathrm{R}$ Core Team 2018), using the package "nparcomp" version 2.6 for paired Brunner-Munzel test (Konietschke et al. 2015), "lmerTest" ver. 3.0-1 for linear mixed models (Kuznetsova et al. 2017), "glmmADMB" ver. 0.8.3.3 for zero-inflated linear and generalized linear mixed models (Fournier et al. 2012; Skaug et al. 2014), "vegan" ver. 2.5-2. for PERMANOVA and NMDS (Oksanen et al. 2018).

\section{Results}

We recorded 401964 flowers of 127 plant species, 1051 wild bee individuals, 893 honey bees and 1177 hoverflies in total, from which we captured 572 wild bees of 73 species, and 756 hoverflies of 22 species (see SM. Table 3). 
Differences between the invaded and control sites in abundance, species richness and diversity

In most cases, we did not find significant differences between the invaded and the control sites in the abundance, species richness and diversity of the studied pollinators (Fig. 1, SM. Table 4). Only, the abundance of honey bees was higher in the invaded sites when the milkweed was flowering ( $p<0.001$; Fig. 1, SM. Table 4) and species richness of wild bees was higher in the invaded sites during the fourth observation date ( $p=0.044$; Fig. 1 , SM. Table 4). However, we found some differences in floral resources between the invaded and the control sites. There was a higher abundance of flowers in the control sites before the flowering of milkweed, and due to the high number of milkweed flowers there was a higher abundance of flowers in the invaded sites when the milkweed was flowering (see SM. Floral resources section).

Effects of the floral resources and the cover of the invasive species

The final multivariate models showed that the abundance of honey bees was positively, while the abundance of hoverflies was negatively affected by the invasion of milkweed (Table 1). The abundance, species richness and diversity of all the studied pollinator groups positively related to the abundance of flowers (Table 1). In addition, the species richness of flowering plants had a significant positive effect on the abundance, species richness and diversity of wild bees, as well as on the species richness and diversity of hoverflies (Table 1). The abundance of hoverflies increased with increasing flower diversity (Table 1).

\section{Community composition of pollinators}

According to the community composition analyses, neither the wild bee, nor the hoverfly communities were significantly influenced by the invasion of milkweed. In contrast, both wild bee and hoverfly communities were significantly influenced by observation date $\left(\mathrm{R}^{2}=0.100, p=0.001\right.$, see SM Fig. 2; $\left.\mathrm{R}^{2}=0.048, \quad p=0.001\right)$, by flower abundances $\left(\mathrm{R}^{2}=0.071 ; p=0.001 ; \mathrm{R}^{2}=0.134 ; p=0.001\right.$, see SM Fig. 2) and by flowering plant species richness $\left(\mathrm{R}^{2}=0.024 ; \quad p=0.013 ; \quad \mathrm{R}^{2}=0.048 ; \quad p=0.002\right.$, respectively) in the final PERMANOVAs. Nevertheless none of the significant variables had a large explanatory strength.

The effects of plant invasion on flower visitation

During the flowering of milkweed, 55\% of wild bees (median; min-max.: 15-98\%), 94\% of honey bees (median; min-max.: 64-100\%) and 13\% of hoverflies (median; min-max.: 0-100\%) visited the common milkweed in the invaded sites. Moreover, different wild bee species visited the common milkweed and the native flowering plants $\left(p=0.015, \mathrm{R}^{2}=0.108\right.$; see SM. Figure 3). In contrast, the wild bee communities visiting the native floral species did not differ between the invaded and control sites at the same time ( $p=0.954, \mathrm{R}^{2}=0.023$; see SM. Figure 3 ). (For the species list of flower visitors of milkweed see SM. Table 3; note: we did not analyze hoverfly communities because of the rare visitation on milkweed, but we also provided the hoverfly species list).

Bumble bees $(p=0.009)$ and honey bees $(p<0.001)$ visited milkweed in a larger abundance than all the native floral species (Fig. 2 and SM. Table 5). However, we did not find differences in their abundances on native floral species between the invaded and control sites in general (except a slightly significant $(p=0.048)$ difference in the case of bumble bees at the third observation date; SM. Figure 4 and SM. Table 5).

\section{Discussion}

We studied the effects of common milkweed on plantpollinator communities. Our results suggest a neutral effect of plant invasion in the studied systems on diurnal pollinators (wild bees and hoverflies), in contrast to most of the former studies, which showed either positive (Lopezaraiza-Mikel et al. 2007; Bartomeus et al. 2008; Russo et al. 2016), or negative effect of invasion by different plant species (Groot et al. 2007; Moroń et al. 2009; Hanula and Horn 2011; Fenesi et al. 2015). Few studies have found the effect of plant invasion to be similarly neutral (Ghazoul 2004; Nielsen et al. 2008; Nienhuis et al. 2009). Davis et al. (2018) raised two basic scenarios of contrasting impacts of invasive plant species on flower-visiting insect communities: 1 . the invasive plant species has a 


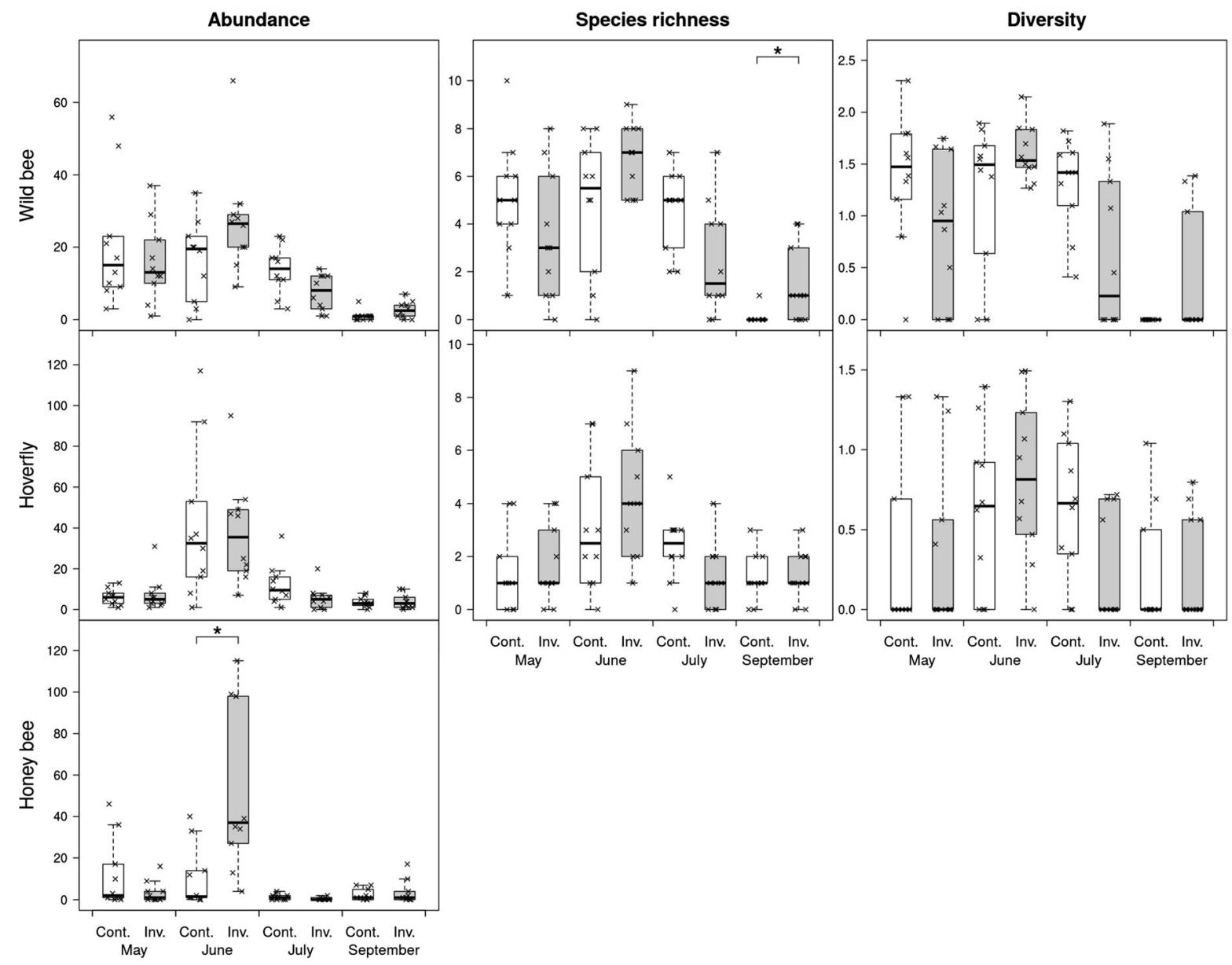

Fig. 1 Abundance, species richness and diversity of wild bees, hoverflies and honey bees in sites invaded by common milkweed (grey boxes) and in uninvaded control sites (white boxes), during four observation dates. Box plots show medians,

negative effect on all pollinator taxa; 2 . the invasive plant species positively affects some pollinators owing to its resource supply, but negatively affects the rest of the pollinator community. We suggest here a new possible outcome, when an invasive plant species has basically a neutral effect on the pollinator community, i.e. does not change the pollinator communities, despite providing suitable resources for some pollinator taxa. But we have to acknowledge that we studied only two groups of diurnal pollinators, obtaining results which do not enable us to describe the whole plant-pollinator system. Hence further investigations are needed also on e.g. nocturnal pollinators (Morse and Fritz 1983) to widen our understanding and applications of the above suggestions in the case of milkweed. Furthermore, this system needs lower and upper quartiles. Black $\times$ symbols represent sampling sites. Significant differences between the invaded and control sites according to the Brunner-Munzel test are indicated by stars (*) above the boxes

investigations on some other important variables to describe plant-pollinator interactions (e.g. pollen deposition and seed set of the wild plants) to be confident that the overall impact is ecologically neutral or not.

The effect of milkweed invasion on floral resources

The floral resources showed only slight (however a few significant) differences between the invaded and control sites (see SM. Floral resources), probably due to the relatively low cover of common milkweed in the studied dry, sandy vegetation. This typical habitat of common milkweed is generally poor in nutrition and water (Gallé et al. 2015; Kelemen et al. 2016; Szitár 
Table 1 Final models explaining abundance, species richness and diversity of wild bees, honey bees and hoverflies in the sites invaded by common milkweed and in the control sites

\begin{tabular}{|c|c|c|c|c|c|c|c|}
\hline Response & variable & $\begin{array}{l}\text { Explanatory variable in final } \\
\text { model }\end{array}$ & Estimate & SE & Exp(estimate) & $p$ value & Model distribution \\
\hline \multirow[t]{6}{*}{ Wild bee } & \multirow[t]{2}{*}{ Abundance } & Flower abundance & 0.00004 & 0.00001 & 1.00004 & $<0.001$ & \multirow[t]{2}{*}{ Quasi Poisson } \\
\hline & & Number of flowering species & 0.04719 & 0.01633 & 1.04832 & 0.006 & \\
\hline & \multirow{2}{*}{$\begin{array}{l}\text { Number of } \\
\text { species }\end{array}$} & Flower abundance & 0.00002 & 0.00001 & 1.00002 & 0.002 & \multirow{2}{*}{$\begin{array}{l}\text { Zero inflated } \\
\text { Poisson }\end{array}$} \\
\hline & & Number of flowering species & 0.04034 & 0.01316 & 1.04116 & 0.002 & \\
\hline & \multirow[t]{2}{*}{ Diversity } & Flower abundance & 0.00003 & 0.00001 & 1.00003 & 0.005 & \multirow{2}{*}{$\begin{array}{l}\text { Zero inflated } \\
\text { Gaussian }\end{array}$} \\
\hline & & Number of flowering species & 0.06582 & 0.01357 & 1.06803 & $<0.001$ & \\
\hline \multirow{2}{*}{$\begin{array}{l}\text { Honey } \\
\text { bee }\end{array}$} & \multirow[t]{2}{*}{ Abundance } & Invaded-control effect & 0.66502 & 0.20843 & 1.94453 & 0.001 & \multirow[t]{2}{*}{ Quasi Poisson } \\
\hline & & Flower abundance & 0.00012 & 0.00002 & 1.00012 & $<0.001$ & \\
\hline \multirow[t]{7}{*}{ Hoverfly } & \multirow[t]{3}{*}{ Abundance } & Invaded-control effect & -0.39520 & 0.15164 & 0.67355 & 0.013 & \multirow[t]{3}{*}{ Quasi Poisson } \\
\hline & & Flower abundance & 0.00006 & 0.00001 & 1.00006 & $<0.001$ & \\
\hline & & Flower diversity & 0.57376 & 0.23368 & 1.77492 & 0.019 & \\
\hline & \multirow{2}{*}{$\begin{array}{l}\text { Number of } \\
\text { species }\end{array}$} & Flower abundance & 0.00004 & 0.00001 & 1.00004 & $<0.001$ & \multirow{2}{*}{$\begin{array}{l}\text { Zero inflated } \\
\text { Poisson }\end{array}$} \\
\hline & & Number of flowering species & 0.03930 & 0.01430 & 1.04008 & 0.006 & \\
\hline & \multirow[t]{2}{*}{ Diversity } & Flower abundance & 0.00002 & 0.00001 & 1.00002 & 0.014 & \multirow{2}{*}{$\begin{array}{l}\text { Zero inflated } \\
\text { Gaussian }\end{array}$} \\
\hline & & Number of flowering species & 0.01968 & 0.00979 & 1.01988 & 0.044 & \\
\hline
\end{tabular}
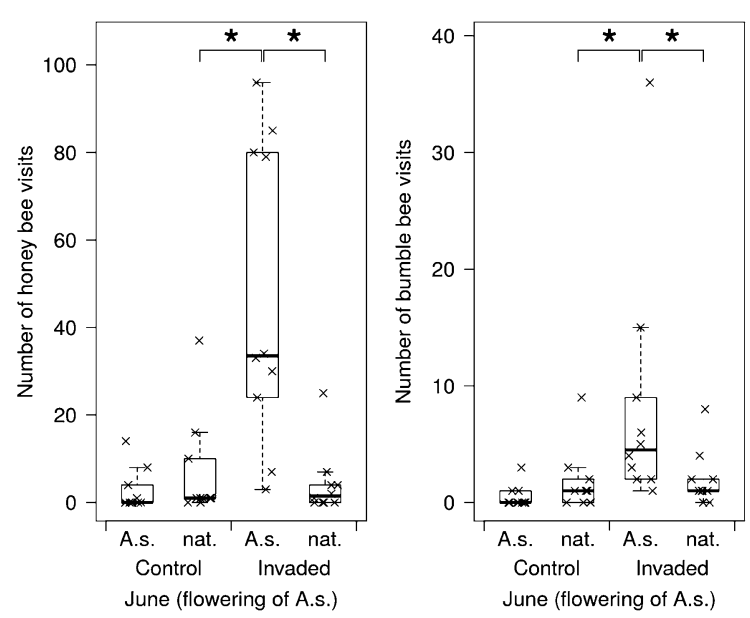

Fig. 2 Abundance of honey bees and bumble bees that visited common milkweed (A.s.) or native floral species (nat.) in the invaded and control sites, during the second observation date (i.e. the flowering of common milkweed). Boxplots show medians, lower and upper quartiles. Black $\times$ symbols represent data per sampling sites. * above the boxes show significant differences according to the Brunner-Munzel test

et al. 2018), where the milkweed does not replace all the native, flowering plant species (Szitár et al. 2018; but see Kelemen et al. 2016), in contrast to several other invasive plants (Dostál et al. 2013; van Hengstum et al. 2014; Fenesi et al. 2015). Hence under milkweed, the native vegetation can still persist, showing similar species pool, but with lower cover as in the non-invaded old fields and grasslands (in milkweed: Csecserits et al. 2011; Kelemen et al. 2016; similarly in other species: Hejda and Pyšek 2008; Montero-Castaño and Vilà 2017). Moreover, being the tallest species in these sandy grasslands, the shadow of milkweed may have a positive micro-climatic effect on the understory vegetation, facilitating the growth of native plants in the dry environment (Botta-Dukát and Balogh 2008; Szitár et al. 2018).

The abundance of flowers was slightly higher in the control sites in May (before the blooming period of milkweed). In contrast, during the blooming period of milkweed in June, the high number of milkweed flowers resulted in higher flower abundance, but lower flower diversity at the same time, in the invaded sites (see SM. Floral resources). Such a contrasting effect on the available amount of flower resources is typical in the case of most flowering, insect-pollinated invasive plant species (e.g. Fenesi et al. 2015; Tiedeken and Stout 2015). The mass-flowering of the invasive species might provide increased flower resource availability for some pollinators (Chittka and Schürkens 2001; Tiedeken and Stout 2015), but the invasive plant often overshadows and influences the 
flowering of the native flora (Dante et al. 2013; Vanbergen et al. 2018). Therefore, common milkweed could have a critical negative effect on foraging resources especially for those pollinator species, which forage actively and reproduce in the end of spring and early summer, and only a lower number of species might benefit from the plentiful nectar of common milkweed in mid-summer.

Changes of pollinator communities under common milkweed invasion

Based on our results the effect of common milkweed invasion seemed to be mostly neutral on pollinator communities, as most of our analyses on pollinators did not show significant difference between the invaded and control sites. The most important difference in pollinator abundance was found in the case of honey bees that were present in significantly higher numbers in the invaded sites during the flowering of milkweed. This result can be explained by the migratory beekeeping, since beekeepers use milkweed to produce varietal honey in Hungary (Farkas and Zajácz 2007; Botta-Dukát and Balogh 2008), placing numerous colonies next to the invaded sites. Although honey bees can find milkweed easily from higher distances as well, they use local floral resources very effectively and usually forage on the actually dominant mass-flowering species (Hung et al. 2019). Milkweed is one of the dominant floral resource species during its blooming peak even at the landscape scale; therefore, it can get a special focus from honey bees.

Apart from honey bees, only the species richness of wild bees showed a marginally significant difference between the invaded and control sites in September, but this difference was so small that we could hardly ascribe to it any particular biological importance. In contrast, the invasion of common milkweed showed a negative effect on the abundance of hoverflies when all the observation dates were analyzed together by the GLM model. It could suggest that most of the hoverflies were not able to forage on milkweed, threatening their presence in the invaded sites. However, analyses of floral resources without milkweed (i.e. the native species exclusively that could be mostly preferred by hoverflies) did not show any difference between the invaded and control sites (see SM. Floral resources). Hence, the negative effect of milkweed invasion on hoverfly abundance may arise from other (non-measured) effects of milkweed, for example reduced resource availability or modified micro-habitats condition for their larvae (Meyer et al. 2009; Moquet et al. 2018). Nevertheless, the larval diet is highly variable among species (Rotheray and Gilbert 2011), thus the effect of milkweed can be antagonistic among hoverfly species at larval stage too.

The similar abundance, species richness and diversity of pollinators between the invaded and control sites can be explained by the similar flower resource availability. All of our measurements on pollinators showed a positive relationship with flower abundance, and many of these with floral richness. These results are in line with previous studies suggesting that the occurrence of pollinators highly depends on the resource availability (Hines and Hendrix 2005; McCracken et al. 2015), and the invasive species mostly drive pollinators through changing floral resources (Chittka and Schürkens 2001; Bezemer et al. 2014). Here the difference in resource availability was usually higher among sites and sampling occasions, than between control and invaded sites, resulting in similar pollinator communities. The seasonality in the species composition, abundance, species richness and diversity of flowering plant species was basically followed by pollinators, as well as the flower visitation that highly varied among the sampling periods (Bagella et al. 2013; Dalmazzo and Vossler 2015).

Another explanation for our neutral results in the case of wild pollinators can be the spatial scale of our study, since plant-pollinator interactions are sensitive to the floral composition of the area in a wider neighborhood (Bartomeus et al. 2010; Albrecht et al. 2016; Charlebois and Sargent 2017; but see also Lopezaraiza-Mikel et al. 2007). Milkweed has been abundant for several decades and integrated into the flora by now in the studied region of Mid-Hungary (Botta-Dukát and Balogh 2008; Novák et al. 2011). Therefore, it probably has a persistent effect on the pollinator communities at a large spatial scale, including our control sites near to our invaded sites. Based on our knowledge, the long-term effects of the establishment of invasive plant species and consequences of their integration into the local flora on the plant-pollinator system have not been studied yet, although it would be worth to investigate. 
Flower visitation on common milkweed vs. the native flora

Despite the mostly similar species richness and abundance of pollinators in the invaded and control site, we found that different bee species visited the flowers of milkweed, than the native plant species during the blooming period of milkweed. The flowers of common milkweed were visited dominantly by honey bees and bumble bees. Milkweed provides primarily nectar that is partly hidden in the flowers (Willson and Bertin 1979; Morse and Fritz 1983) and inaccessible to many flower visitors such as shorttongued wild bees and hoverflies. As our results also demonstrate, honey bees and bumble bees might benefit more from plant invasions by exploiting the new resources (Nielsen et al. 2008; Drossart et al. 2017) due to their morphological and phenological characteristics and generalist foraging strategy (Morales and Traveset 2009; Stout and Tiedeken 2017; Davis et al. 2018). Besides, these large generalist social bees with larger home ranges and informative communication among the foragers can respond to local changes in floral availability more easily, exploring larger areas at the landscape scale, and reaching resources with wider range of floral structure (Bezemer et al. 2014; Tiedeken and Stout 2015; Albrecht et al. 2016).

Common milkweed is a self-incompatible species (Howard and Barrows 2014), therefore the abundant visitation of honey bees and bumble bees probably increases its sexual reproduction success (Morse and Fritz 1983). It is one of the most important strategies to increase adaptability of an invasive plant species in a new environment and to spread over the landscape (Richardson et al. 2000; Bartomeus et al. 2010; Ward et al. 2012; Wojcik et al. 2018). The attractiveness of the invasive common milkweed for some pollinators is an advantage for the milkweed, but could be a disadvantage for the co-flowering native plant species (Chittka and Schürkens 2001; Brown et al. 2002; Albrecht et al. 2016; Dante et al. 2013; Carvalheiro et al. 2014; but see Charlebois and Sargent 2017). Although, the number of visitations on the native flowers by honey and bumble bees did not differ between our neighboring invaded and non-invaded sites, the high number of milkweed visitation may depress native floral species due to a competition effect at the landscape scale. Altered flower visitation probably can enhance advancing and stabilizing of milkweed in the invaded and degraded habitat types, hampering the desired succession to a more natural vegetation (Meiners et al. 2002; Fenesi et al. 2015).

\section{Conservation implications}

Despite the lack of considerable negative effects of milkweed on pollinators in the studied sandy old fields, its invasion causes serious conservation problems in the European natural and semi-natural habitats, as well as in agriculture (Botta-Dukát and Balogh 2008; Novák et al. 2011; Kelemen et al. 2016; Lapin 2017; Szitár et al. 2018). Although the studied old fields are not the primary focus of conservation, these sites are highly susceptible to common milkweed invasion (Csecserits et al. 2011; Szitár et al. 2018), and can be a starting point for further invasion, jeopardizing other habitats at landscape or regional scales (Standish et al. 2008; Catford et al. 2012; Csecserits et al. 2016). Nevertheless, old fields can also support farmland biodiversity, and deliver valuable ecosystem services (e.g. pollination) (Corbet 1995; Csecserits et al. 2011; Tscharntke et al. 2011). In a longer timescale, old fields can turn into semi-natural habitats (Stoate et al. 2009; Csecserits et al. 2011; Albert et al. 2014), but the trajectory of succession can be seriously hampered by plant invasion (Botta-Dukát and Balogh 2008; Albert et al. 2014; but see also Csecserits et al. 2011).

Moreover, beside the extensive utilization by beekeepers in honey production (Farkas and Zajácz 2007; Botta-Dukát and Balogh 2008), some wild bee species, especially bumble bees (as well as probably other non-studied taxa, e.g. moths and butterflies) may make use of milkweed's floral rewards. Nevertheless, despite the lack of direct negative effects on wild pollinators, restoration of invaded habitats to promote native floral communities is suggested to enable diverse and longer lasting foraging resources for wild pollinators and honey bees. But, instead of simple eradication (e.g. cut milkweed before/during flowering or using herbicides, Csiszár and Korda 2015; Lapin 2017) one should reconsider the conservation management against milkweed. For example, during the process of milkweed eradication and/or restoration, it might be worth promoting pollinators by providing alternative floral resources (e.g. sown wildflowers on adjacent unmanaged fallows), which 
could be vital for beekeepers as well. To ensure native floral resources and protect old fields from the establishment of any other invasive species, natural succession processes from old field into natural biotopes should be enhanced by locally adapted restoration processes, which pose significant challenges to conservationists (Caut et al. 2009; Simberloff et al. 2013; Csiszár and Korda 2015; Csecserits et al. 2016; Davis et al. 2018; Szitár et al. 2018).

\section{Further research questions}

In agreement with Hulme et al. (2013), Stout and Tiedeken (2017) and Vanbergen et al. (2018), further studies are needed to better understand the consequences of plant invasion on plant-pollinator interactions at different spatio-temporal scales as well as at different level of organizations. Small spatial scale experiments (Chittka and Schürkens 2001), comparison of similar invaded and control sites (see our study or Davis et al. 2018), landscape or country scale studies (Bezemer et al. 2014; Albrecht et al. 2016) can all widen our knowledge on plant invasion. Similarly, to reveal the effect of invasion on the daily rhythm of flower visitors (Herrera 1990; Bloch et al. 2017) including nocturnal pollinators e.g. in the case of milkweed, which is also visited by various nocturnal moth species in North America (Morse and Fritz 1983), investigating throughout the season (see our study or Bartomeus et al. 2010; Tiedeken and Stout 2015) as well as applying long-term investigations (Meiners et al. 2002), combined with experiments on eradication (Albrecht et al. 2016; Kaiser-Bunbury et al. 2017) would be still necessary. Nevertheless, we made observations in highly degraded old fields, abandoned 5-20 years ago (probably with some uncertainties in their agricultural history) that can show only a snapshot about the existing differences between invaded and non-invaded sites. Hence, we suggest that the former land use can also influence the results of invasion, which could be worth for further investigation (Dostál et al. 2013; Hulme et al. 2013; Fenesi et al. 2015; Csecserits et al. 2016). Last but not least, community level analyses cannot reveal the differences in flower visitation at pollinator individual or population level (Hulme et al. 2013; Stout and Tiedeken 2017; Hansen et al. 2018), hence studying the effects of plant invasion at different organization levels (from individual behavior to plant-pollinator networks) is essential to understand the consequences in more detail.

Acknowledgements Open access funding provided by ELKH Centre for Ecological Research. We thank to András Báldi for his valuable comments on the former version of the manuscript, Csaba Molnár for identifying and sampling floral resources, Zsolt Józan for identification of wild bees, Tamás Grőb for preparing hoverflies, Márton Vörös for field work assistance. We also thank to the following persons for their help in the study site selection: Danube-Ipoly National Park: Sándor Bérces, Zsolt Kepes, Valentin Szénási, Tamás Vidra; Kiskunság National Park: Csaba Bíró, Ferenc Pál Szabó, Ferenc Sipos, István Somogyi, Ádám Tamás, Csaba Vadász; Pilisi Parkerdő Zrt. Valkói Erdészet: Bence Kiss. The Landscape Ecological Vegetation Database \& Map of Hungary (MÉTA database) was used as data source for the study site selection (https://www. novenyzetiterkep.hu/english/). The study was financed by the National Research, Development and Innovation Office (FK 123813). Field work was licensed by the Hungarian Nature Conservation Authorities: PE-KTFO/267-15/2018. A K-H. was a Bolyai János Research Fellow of the MTA.

Open Access This article is licensed under a Creative Commons Attribution 4.0 International License, which permits use, sharing, adaptation, distribution and reproduction in any medium or format, as long as you give appropriate credit to the original author(s) and the source, provide a link to the Creative Commons licence, and indicate if changes were made. The images or other third party material in this article are included in the article's Creative Commons licence, unless indicated otherwise in a credit line to the material. If material is not included in the article's Creative Commons licence and your intended use is not permitted by statutory regulation or exceeds the permitted use, you will need to obtain permission directly from the copyright holder. To view a copy of this licence, visit http://creativecommons.org/licenses/by/4.0/.

\section{References}

Albert ÁJ, Kelemen A, Valkó O et al (2014) Secondary succession in sandy old-fields: a promising example of spontaneous grassland recovery. Appl Veg Sci 17:214-224. https://doi.org/10.1111/avsc. 12068

Albrecht M, Padrón B, Bartomeus I, Traveset A (2014) Consequences of plant invasions on compartmentalization and species' roles in plant-pollinator networks. Proc R Soc B 281:20140773. https://doi.org/10.1098/rspb.2014.0773

Albrecht M, Ramis MR, Traveset A (2016) Pollinator-mediated impacts of alien invasive plants on the pollination of native plants: the role of spatial scale and distinct behaviour among pollinator guilds. Biol Invasions 18:1801-1812. https://doi.org/10.1007/s10530-016-1121-6

Bagella S, Satta A, Floris I et al (2013) Effects of plant community composition and flowering phenology on honeybee foraging in Mediterranean sylvo-pastoral systems. Appl Veg Sci 16:689-697. https://doi.org/10.1111/avsc.12023 
Bartomeus I, Vilà M, Santamaría L (2008) Contrasting effects of invasive plants in plant-pollinator networks. Oecologia 155:761-770. https://doi.org/10.1007/s00442-007-0946-1

Bartomeus I, Vilà M, Steffan-Dewenter I (2010) Combined effects of Impatiens glandulifera invasion and landscape structure on native plant pollination. J Ecol 98:440-450. https://doi.org/10.1111/j.1365-2745.2009.01629.x

Benjamini Y, Hochberg Y (1995) Controlling the false discovery rate: a practical and powerful approach to multiple testing. J R Stat Soc Ser B 57:289-300

Bezemer TM, Harvey JA, Cronin JT (2014) Response of native insect communities to invasive plants. Annu Rev Entomol 59:119-141. https://doi.org/10.1146/annurev-ento011613-162104

Bloch G, Bar-Shai N, Cytter Y, Green R (2017) Time is honey: circadian clocks of bees and flowers and how their interactions may influence ecological communities. Philos Trans R Soc B Biol Sci 372:1-11. https://doi.org/10.1098/ rstb.2016.0256

Borcard D, Gillet F, Legendre P (2018) Numerical Ecology with $R, 2$ nd edn. Springer, New York

Botta-Dukát Z, Balogh L (2008) The most important invasive plants in Hungary. Institute of Ecology and Botany Hungarian Academy of Science, New Delhi

Brown BJ, Mitchell RJ, Graham SA (2002) Competition for pollination between an invasive species (purple loosestrife) and a native congener. Ecology 83:2328-2336

Carvalheiro LG, Biesmeijer JC, Benadi G et al (2014) The potential for indirect effects between co-flowering plants via shared pollinators depends on resource abundance, accessibility and relatedness. Ecol Lett 17:1389-1399. https://doi.org/10.1111/ele.12342

Catford JA, Daehler CC, Murphy HT et al (2012) The intermediate disturbance hypothesis and plant invasions: implications for species richness and management. Perspect Plant Ecol Evol Syst 14:231-241. https://doi.org/10. 1016/j.ppees.2011.12.002

Caut S, Angulo E, Courchamp F (2009) Avoiding surprise effects on Surprise Island: alien species control in a multitrophic level perspective. Biol Invasions 11:1689-1703. https://doi.org/10.1007/s10530-008-9397-9

Charlebois JA, Sargent RD (2017) No consistent pollinatormediated impacts of alien plants on natives. Ecol Lett 20:1479-1490. https://doi.org/10.1111/ele.12831

Chittka L, Schürkens S (2001) Successful invasion of a floral market. Nature 411:653. https://doi.org/10.1038/35079676

Clarke KR, Somerfield PJ, Chapman MG (2006) On resemblance measures for ecological studies, including taxonomic dissimilarities and a zero-adjusted Bray-Curtis coefficient for denuded assemblages. J Exp Mar Bio Ecol 330:55-80. https://doi.org/10.1016/j.jembe.2005.12.017

Corbet SA (1995) Insects, plants and succession: advantages of long-term set-aside. Agric Ecosyst Environ 53:201-217. https://doi.org/10.1016/0167-8809(94)00581-X

Cramer VA, Hobbs RJ, Standish RJ (2008) What's new about old fields? Land abandonment and ecosystem assembly. Trends Ecol Evol 23:104-112. https://doi.org/10.1016/j. tree.2007.10.005

Csecserits A, Botta-Dukát Z, Kröel-Dulay G et al (2016) Tree plantations are hot-spots of plant invasion in a landscape with heterogeneous land-use. Agric Ecosyst Environ 226:88-98. https://doi.org/10.1016/j.agee.2016.03.024

Csecserits A, Czúcz B, Halassy M et al (2011) Regeneration of sandy old-fields in the forest steppe region of Hungary. Plant Biosyst 145:715-729. https://doi.org/10.1080/ 11263504.2011.601340

Csiszár Á, Korda M (2015) Özönnövények visszaszorításának gyakorlati tapasztalatai. Duna-Ipoly Nemzeti Park Igazgatóság, Budapest

Dalmazzo M, Vossler FG (2015) Pollen host selection by a broadly polylectic halictid bee in relation to resource availability. Arthropod Plant Interact 9:253-262. https:// doi.org/10.1007/s11829-015-9364-1

Dante SK, Schamp BS, Aarssen LW (2013) Evidence of deterministic assembly according to flowering time in an old-field plant community. Funct Ecol 27:555-564. https:// doi.org/10.1111/1365-2435.12061

Davis ES, Kelly R, Maggs CA, Stout JC (2018) Contrasting impacts of highly invasive plant species on flower-visiting insect communities. Biodivers Conserv 27:2069-2085. https://doi.org/10.1007/s10531-018-1525-y

De Groot GM, Kleijn D, Jogan N (2007) Species groups occupying different trophic levels respond differently to the invasion of semi-natural vegetation by Solidago canadensis. Biol Conserv 136:612-617. https://doi.org/10.1016/j. biocon.2007.01.005

Dicks L, Abrahams A, Atkinson J et al (2013) Identifying key knowledge needs for evidence-based conservation of wild insect pollinators: a collaborative cross-sectoral exercise. Insect Conserv Divers 6:435-446. https://doi.org/10.1111/ j.1752-4598.2012.00221.x

Dostál P, Müllerová J, Pyšek P et al (2013) The impact of an invasive plant changes over time. Ecol Lett 16:1277-1284. https://doi.org/10.1111/ele.12166

Drossart M, Michez D, Vanderplanck M (2017) Invasive plants as potential food resource for native pollinators: a case study with two invasive species and a generalist bumble bee. Sci Rep 7:1-12. https://doi.org/10.1038/s41598-01716054-5

EU list (2017) Consolidated list of invasive alien species of Union concern https://ec.europa.eu/environment/nature/ invasivealien/list/index_en.htm

Farkas Á, Zajácz E (2007) Nectar production for the Hungarian honey industry. Eur J Plant Sci Biotechnol 1:125-151

Fehér P (2004) Méhlegelőink feketelistán. Méhészet 7:21

Fenesi A, Vágási CI, Beldean $\mathrm{M}$ et al (2015) Solidago canadensis impacts on native plant and pollinator communities in different-aged old fields. Basic Appl Ecol 16:335-346. https://doi.org/10.1016/j.baae.2015.03.003

Fenster CB, Armbruster WS, Wilson P et al (2004) Pollination syndromes and floral specialization. Annu Rev Ecol Evol Syst 35:375-403. https://doi.org/10.1146/annurev.ecolsys. 34.011802.132347

Fournier DA, Skaug HJ, Ancheta J et al (2012) AD model builder: using automatic differentiation for statistical inference of highly parameterized complex nonlinear models. Optim Methods Softw 27:233-249. https://doi. org/10.1080/10556788.2011.597854

Gallé R, Erdélyi N, Szpisjak N et al (2015) The effect of the invasive Asclepias syriaca on the ground-dwelling 
arthropod fauna. Biologia (Bratisl) 70:104-112. https:// doi.org/10.1515/biolog-2015-0011

Ghazoul J (2004) Alien abduction: disruption of native plantpollinator interactions by invasive species. Biotropica 36:156-164

Goodell K, Parker IM (2017) Invasion of a dominant floral resource: Effects on the floral community and pollination of native plants. Ecology 98:57-69. https://doi.org/10. 1002/ecy.1639

Hansen S, Roets F, Seymour CL et al (2018) Alien plants have greater impact than habitat fragmentation on native insect flower visitation networks. Divers Distrib 24:58-68. https://doi.org/10.1111/ddi.12656

Hanula JL, Horn S (2011) Removing an invasive shrub (Chinese privet) increases native bee diversity and abundance in riparian forests of the southeastern United States. Insect Conserv Divers 4:275-283. https://doi.org/10.1111/j.17524598.2011.00131.x

Hejda M, Pyšek P (2008) Estimating the community-level impact of the riparian alien species Mimulus guttatus by using a replicated BACI field experiment. NeoBiota $7: 250-257$

Herrera C (1990) Daily patterns of pollinator activity, differential pollinating effectiveness, and floral resource availability, in a summer-flowering Mediterranean shrub. Oikos 3:277-288

Hines H, Hendrix S (2005) Bumble bee (Hymenoptera: Apidae) diversity and abundance in tallgrass prairie patches: effects of local and landscape floral resources. Environ Entomol 34:1477-1484

Howard AF, Barrows EM (2014) Self-pollination rate and floral-display size in Asclepias syriaca (Common Milkweed) with regard to floral-visitor taxa. BMC Evol Biol 14:1-16. https://doi.org/10.1186/1471-2148-14-144

Hulme PE, Pyšek P, Jarošík V et al (2013) Bias and error in understanding plant invasion impacts. Trends Ecol Evol 28:212-218. https://doi.org/10.1016/j.tree.2012.10.010

Hung KLJ, Kingston JM, Lee A et al (2019) Non-native honey bees disproportionately dominate the most abundant floral resources in a biodiversity hotspot. Proc R Soc B Biol Sci. https://doi.org/10.1098/rspb.2018.2901

Kaiser-Bunbury CN, Mougal J, Whittington AE et al (2017) Ecosystem restoration strengthens pollination network resilience and function. Nature 542:223-227. https://doi. org/10.1038/nature21071

Kelemen A, Valkó O, Kröel-Dulay G et al (2016) The invasion of common milkweed (Asclepias syriaca) in sandy oldfields - is it a threat to the native flora? Appl Veg Sci 19:218-224. https://doi.org/10.1111/avsc. 12225

Klein A-M, Vaissiere BE, Cane JH et al (2007) Importance of pollinators in changing landscapes for world crops. Proc R Soc B Biol Sci 274:303-313. https://doi.org/10.1098/rspb. 2006.3721

Knight TM, Ashman TL, Bennett JM et al (2018) Reflections on, and visions for, the changing field of pollination ecology. Ecol Lett 21:1282-1295. https://doi.org/10.1111/ele. 13094

Konietschke F, Placzek M, Schaarschmidt F, Hothorn LA (2015) nparcomp: An R software package for nonparametric multiple comparisons and simultaneous confidence intervals. J Stat Softw 64:1-17. https://doi.org/10.18637/ jss.v064.i09

Kuznetsova A, Brockhoff PB, Christensen RHB (2017) lmerTest package: Tests in linear mixed effects models. J Stat Softw 82:1-26

Lapin K (2017) Information on measures and related costs in relation to species included on the Union list: Asclepias syriaca. Technical note prepared by IUCN for the European Commission. https://circabc.europa.eu/sd/a/ 854cb8c6-fd41-4ce6-92ed-8c431fe1b959/TSSR-20

Larson DL, Royer RA, Royer MR (2006) Insect visitation and pollen deposition in an invaded prairie plant community. Biol Conserv 130:148-159. https://doi.org/10.1016/j. biocon.2005.12.009

Liede S, Weberling F (1995) On the inflorescence structure of Asclepiadaceae. Plant Syst Evol 197:99-109. https://doi. org/10.1007/BF00984635

Lopezaraiza-Mikel ME, Hayes RB, Whalley MR, Memmott J (2007) The impact of an alien plant on a native plantpollinator network: an experimental approach. Ecol Lett 10:539-550. https://doi.org/10.1111/j.1461-0248.2007. 01055.x

McCracken ME, Woodcock BA, Lobley M et al (2015) Social and ecological drivers of success in agri-environment schemes: the roles of farmers and environmental context. J Appl Ecol 52:696-705. https://doi.org/10.1111/13652664.12412

Meiners SJ, Pickett STA, Cadenasso ML (2002) Exotic plant invasions over 40 years of old field successions: Community patterns and associations. Ecography 25:215-223. https://doi.org/10.1034/j.1600-0587.2002.250209.x

Meyer B, Jauker F, Steffan-Dewenter I (2009) Contrasting resource-dependent responses of hoverfly richness and density to landscape structure. Basic Appl Ecol 10:178-186. https://doi.org/10.1016/j.baae.2008.01.001

Montero-Castaño A, Vilà M (2017) Influence of the honeybee and trait similarity on the effect of a non-native plant on pollination and network rewiring. Funct Ecol 31:142-152. https://doi.org/10.1111/1365-2435.12712

Moquet L, Laurent E, Bacchetta R, Jacquemart A-L (2018) Conservation of hoverflies (Diptera, Syrphidae) requires complementary resources at the landscape and local scales. Insect Conserv Divers 11:72-87. https://doi.org/10.1111/ icad. 12245

Morales CL, Traveset A (2009) A meta-analysis of impacts of alien vs. native plants on pollinator visitation and reproductive success of co-flowering native plants. Ecol Lett 12:716-728. https://doi.org/10.1111/j.1461-0248.2009. 01319.x

Moroń D, Lenda M, Skórka P et al (2009) Wild pollinator communities are negatively affected by invasion of alien goldenrods in grassland landscapes. Biol Conserv 142:1322-1332. https://doi.org/10.1016/j.biocon.2008.12. 036

Morse DH (1981) Modification of bumblebee foraging: the effect of milkweed pollinia. Ecology 62:89-97. https://doi. org/10.2307/1936672

Morse DH, Fritz RS (1983) Contributions of diurnal and nocturnal insects to the pollination of common milkweed (Asclepias syriaca L.) in a pollen-limited system. 
Oecologia 60:190-197. https://doi.org/10.1007/ BF00379521

Munzel U, Brunner E (2002) An exact paired rank test. Biometrical J 44:584-593

Nielsen C, Heimes C, Kollmann J (2008) Little evidence for negative effects of an invasive alien plant on pollinator services. Biol Invasions 10:1353-1363. https://doi.org/10. 1007/s10530-007-9210-1

Nienhuis CM, Dietzsch AC, Stout JC (2009) The impacts of an invasive alien plant and its removal on native bees. Apidologie 40:450-463. https://doi.org/10.1051/apido/ 2009005

Novák R, Dancza I, Szentey L, Karamán J (2011) Az ötödik országos gyomfelvételezés Magyarország szántóföldjein. Vidékfejlesztési Minisztérium Élelmiszerlánc-felügyeleti Főosztály Növény- és Talajvédelmi Osztály

Oksanen J, Blanchet FG, Friendly M, et al (2018) vegan: Community ecology package. https://cran.r-project.org/ package $=$ vegan

Olesen JM, Eskildsen LI, Venkatasamy S (2002) Invasion of pollination networks on oceanic islands: Importance of invader complexes and endemic super generalists. Divers Distrib 8:181-192. https://doi.org/10.1046/j.1472-4642. 2002.00148.x

Ollerton J (2017) Pollinator diversity: Distribution, ecological function, and conservation. Annu Rev Ecol Evol Syst 48:353-376. https://doi.org/10.1146/annurev-ecolsys110316-022919

Potts SG, Ngo HT, Biesmeijer JC et al (2016) The assessment report of the intergovernmental science-policy platform on biodiversity and ecosystem services on pollinators, pollination and food production. Secretariat of the Intergovernmental Science-Policy Platform on Biodiversity and Ecosystem Services, Bonn

R Core Team (2018) R: A language and environment for statistical computing. https://www.r-project.org/

Richardson DM, Allsopp N, D'Antonio CM et al (2000) Plant invasions - the role of mutualisms. Biol Rev Camb Philos Soc 75:65-93. https://doi.org/10.1111/j.1469-185X.1999. tb00041.x

Rotheray GE, Gilbert F (2011) The natural history of hoverflies. Forrest Text, Tresaith

Russo L, Nichol C, Shea K (2016) Pollinator floral provisioning by a plant invader: quantifying beneficial effects of detrimental species. Divers Distrib 22:189-198. https://doi.org/ 10.1111/ddi.12397

Simberloff D, Martin JL, Genovesi P et al (2013) Impacts of biological invasions: What's what and the way forward. Trends Ecol Evol 28:58-66. https://doi.org/10.1016/j.tree. 2012.07.013

Skaug H, Fournier D, Bolker B et al (2014) Generalized linear mixed models using AD model builder. http://glmmadmb. r-forge.r-project.org

Standish RJ, Cramer VA, Hobbs RJ (2008) Land-use legacy and the persistence of invasive Avena barbata on abandoned farmland. J Appl Ecol 45:1576-1583. https://doi.org/10. 1111/j.1365-2664.2008.01558.x
Stoate C, Báldi A, Beja P et al (2009) Ecological impacts of early 21st century agricultural change in Europe - A review. J Environ Manage 91:22-46. https://doi.org/10. 1016/j.jenvman.2009.07.005

Stout JC, Tiedeken EJ (2017) Direct interactions between invasive plants and native pollinators: evidence, impacts and approaches. Funct Ecol 31:38-46. https://doi.org/10. $1111 / 1365-2435.12751$

Szalóky I (2004) Méhlegelőink feketelistán. Méhészet 9:14-15

Szitár K, Kröel-Dulay G, Török K (2018) Invasive Asclepias syriaca can have facilitative effects on native grass establishment in a water-stressed ecosystem. Appl Veg Sci 21:607-614. https://doi.org/10.1111/avsc.12397

Tiedeken EJ, Stout JC (2015) Insect-flower interaction network structure is resilient to a temporary pulse of floral resources from invasive Rhododendron ponticum. PLoS ONE. https://doi.org/10.1371/journal.pone.0119733

Traveset A, Richardson DM (2014) Mutualistic interactions and biological invasions. Annu Rev Ecol Evol Syst 45:89-113. https://doi.org/10.1146/annurev-ecolsys-120213-091857

Tscharntke T, Batáry P, Dormann CF (2011) Set-aside management: How do succession, sowing patterns and landscape context affect biodiversity? Agric Ecosyst Environ 143:37-44. https://doi.org/10.1016/j.agee.2010.11.025

van Hengstum T, Hooftman DAP, Oostermeijer JGB, van Tienderen PH (2014) Impact of plant invasions on local arthropod communities: a meta-analysis. J Ecol 102:4-11. https://doi.org/10.1111/1365-2745.12176

Vanbergen AJ, Espíndola A, Aizen MA (2018) Risks to pollinators and pollination from invasive alien species. Nat Ecol Evol 2:16-25. https://doi.org/10.1038/s41559-017-0412-3

Venables WN, Ripley BD (2002) Modern applied statistics with S, 4th edn. Springer, New York

Vítková M, Müllerová J, Sádlo J et al (2017) Black locust (Robinia pseudoacacia) beloved and despised: a story of an invasive tree in Central Europe. For Ecol Manage 384:287-302. https://doi.org/10.1016/j.foreco.2016.10. 057

Ward M, Johnson SD, Zalucki MP (2012) Modes of reproduction in three invasive milkweeds are consistent with Baker's Rule. Biol Invasions 14:1237-1250. https://doi. org/10.1007/s10530-011-0152-2

Willson MF, Bertin RI (1979) Flower-visitors, nectar production, and inflorescence size of Asclepias syriaca. Can J Bot 57:1380-1388. https://doi.org/10.1139/b79-172

Wojcik VA, Morandin LA, Davies Adams L, Rourke KE (2018) Floral resource competition between honey bees and wild bees: is there clear evidence and can we guide management and conservation? Environ Entomol 47:822-833. https:// doi.org/10.1093/ee/nvy077

Zuur A, Ieno EN, Walker N et al (2009) Mixed effects models and extensions in ecology with R. Springer, New York

Publisher's Note Springer Nature remains neutral with regard to jurisdictional claims in published maps and institutional affiliations. 